\title{
Fiscal space for sustainable financing of health systems and universal health*
}

\author{
Camilo Cid Pedraza, ${ }^{1}$ Juan Pablo Pagano, ${ }^{1}$ Claudia Pescetto, ${ }^{1}$ and Lorena Prieto ${ }^{1}$
}

Suggested citation (original article) Cid Pedraza C, Pagano JP, Pescetto C, Prieto L. Espacio fiscal para el financiamiento sostenible de los sistemas de salud y la salud universal. Rev Panam Salud Publica. 2018;42:e197. https://doi.org/10.26633/RPSP.2018.197

ABSTRACT The articles published in this series show that it is possible to create fiscal space for health in countries. This
requires specific decisions since economic growth is not enough to generate the additional resources needed.
The studies analyze the benefits of reviewing tax expenditures to identify exemptions, which are generally
outdated and of low benefit for the countries; arguments in favor of increasing taxes on products harmful to
health; and credits and donations, which do not result in a viable source of income for governments. Fiscal
efforts must be accompanied by an improvement in efficiency, and the progressive creation of new revenues
is key to improving equity. It is necessary to improve the collection of fiscal resources.
It is necessary to develop a research and action agenda that includes the analysis of fiscal space within the
processes of health system transformation and reform, including technical aspects not yet addressed and
studies of the social efficiency of fiscal space for major development objectives such as the Sustainable Devel-
opment Goals 2030 . In the countries of the Region of the Americas it is essential to have efficient management
to do more and better with more resources, even during adverse economic cycles. This should be evident at all
levels, including solidarity for achieving better health outcomes, the strategic purchase of goods and services
for health, and the strengthening of budget planning systems.

This series includes a set of articles on financing and fiscal space for health in the countries of the Americas. The series begins with two articles: (1) an editorial by the Director of PAHO that presents the policy framework underlying the need to increase public expenditure in health and reduce direct out-of-pocket payments; and (2) a regional analysis of the possibility of such an increase based exclusively on favorable macroeconomic conditions that translate into growth. It concludes that this is not sufficient, that doing nothing is unproductive, and that countries must take specific measures to increase fiscal space for health if we are to move toward universal health (2).

Subsequent articles on fiscal space for Peru (3), Bolivia (4), Honduras (5), and Suriname (6) follow specific lines with a common methodology and technical aspects. They consider the sources of fiscal space for each individual country and its political economy.

In the article on health accounts, a link is made between financial accounting as a way to keep track of investments in health and policies to increase fiscal space (7). The work done on out-of-pocket expenditures in Peru shows the determinants that affect the poorest people and underscores the importance of redirecting financial protection policies to increase public expenditure (8). The Grenada study explores tobacco excise taxes as a possible source of financing (9).

This last article in the series highlights the salient points of the published papers and shows the importance of giving guidance for future progress in this field. It stresses that progress comes about not only through new studies, but also through interactions among different activities that support the needs

\footnotetext{
* Official English translation from the original Spanish manuscript made by the Pan American Health Organization. In case of discrepancy, the original version (Spanish) shall prevail.
} 
TABLE 1. Sources of fiscal space discussed by the authors of the articles in the series ${ }^{a}$

\begin{tabular}{l}
\multicolumn{1}{c}{ Source of fiscal space } \\
\cline { 2 - 4 } \\
Economic growth/favorable macroeconomic conditions
\end{tabular}

Only the six articles that measure fiscal space are included

Source: the author. Adapted by PAHO, 2018 (10).

for sustainable financing and the changes required of health systems in the countries.

\section{MATERIALS AND METHODS}

The concept of fiscal space and its links to health emerged during efforts to achieve the Millennium Development Goals. A systematic approach was established by staff at the International Monetary Fund and the World Bank, especially during the 2000s (10). It was then reconsidered by the Pan American Health Organization/World Health Organization (PAHO/WHO) in the context of promoting the Strategy for Universal Access to Health and Universal Health Coverage in 2014 and the subsequent commitment to increase efficiency and equity in public expending in health in order to gradually eliminate out-of-pocket expenditure (11).

The concept refers to the capacity of governments to allocate additional budgetary resources for the health system, without affecting the financial situation of the public sector or displacing other necessary social spending (12). It also stresses the sustainability of a government's financial position in situations in which additional resources must be tapped for health, in this case, in order to advance toward universal access and universal coverage.

The methodology used in the fiscal space studies consists of a diagnosis of potential sources of additional funding for the health system and an assessment of the potential amounts and political viability in each specific case. In this context, the goal is to elucidate how to obtain more revenue through taxes or other means, while giving equal importance to the distribution of expenditure, organizational improvements that may lead to greater equity, and processes for obtaining political acceptance of the measures.

The complementary studies use a variety of methodologies to uphold their stated hypotheses: one is a descriptive study of health accounts, indicators, their usefulness, and history; another uses an econometric method for establishing determinants and the impact of out-of-pocket spending; and one specifically measures quantitative increases in tobacco taxes.

Table 1 shows the topics discussed in the six articles on measuring fiscal space.
FIGURE 1. The five sources of fiscal space for health

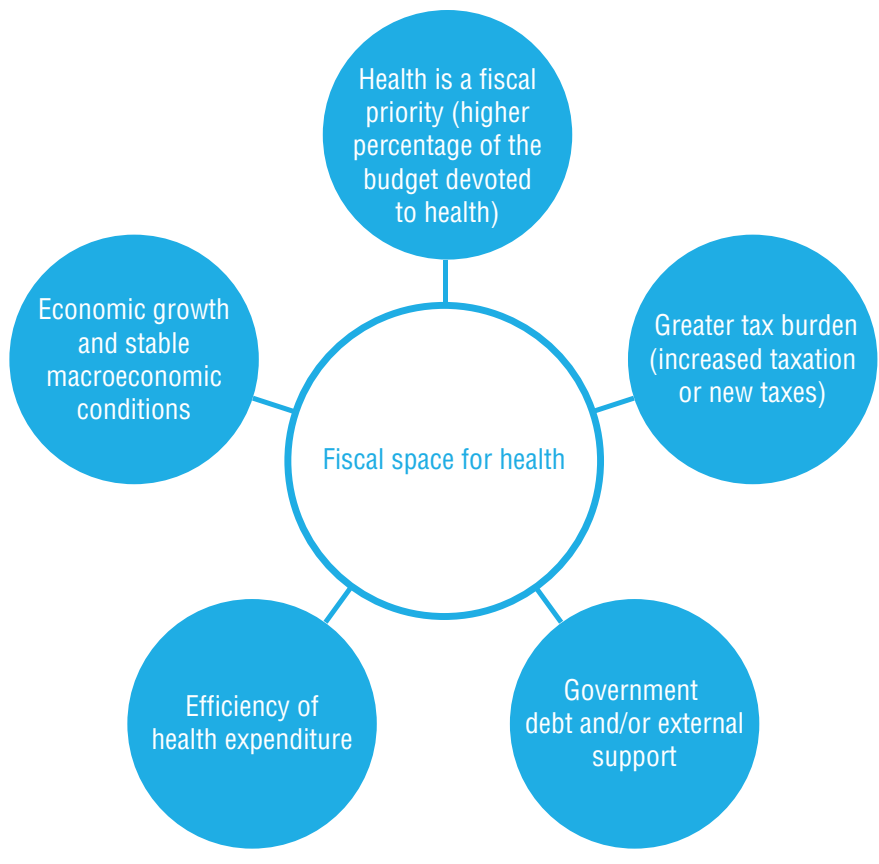

Source: the author.

\section{RESULTS AND DISCUSSION}

Economic growth and favorable macroeconomic conditions are the most studied sources of fiscal space. Generally when an economy has stable growth, if tax collection increases and the distribution of government spending remains the same across sectors, once would expect an increase in economic resources for health. However, it has been proven that this is not enough.

In fact, if the Region continues to prioritize health based on future economic growth as it has for the past 20 years, only 
four more countries in Latin America and the Caribbean would achieve the goal of increasing public expenditure in health to $6 \%$ of GDP by 2030 (aside from the three countries that have already done so), and many would not achieve this until the end of the century or never (2).

Given the low fiscal priority given to health in the Region $(10,13)$, a reprioritization of the health budget within total public expenditure would appear to be an important source of fiscal space, but this is hindered by the rigid structure of public spending.

There are two things to consider regarding reprioritization: there can be an increase in the weight given to health expenditure compared to total public expenditure, or there can be an increase in social expenditure as a whole. In the latter case, the goal is to prevent health expenditure from competing with other items that complement the intersectoral approach to health. This points to reprioritization, aside from any budgetary increase.

For example, in Peru the problem of health sector financing has more to do with the overall volume of government revenue than with the prioritization of health (3). In Bolivia, however, government revenue has been moderately high, but health has been a low fiscal priority, which means there are potential gains to be made in fiscal space (4).

Sources of new revenue are divided into tax revenue and compulsory social contributions. Taxes offer more opportunities, ranging from increasing the tax burden and creating new taxes (including on items that are harmful to health), to reducing tax expenditures or exemptions. The goal is to increase collections and allocate part of that increase to health. There must be an active effort, not just inertia.

When these political decisions are made, one should be aware that taxation systems based primarily on indirect taxes, as is the case in most countries in the Region, tend to be regressive. Progressive taxation (such as income tax and taxes on wealth) is desirable because it has an impact on general equity and evidence shows that it is also associated with improvements in health (14, 15). One should also bear in mind the low tax burden of the countries of the Region which is both a problem and an opportunity.

In this context, Peru has favored thee expansion of a progressive tax burden on income, but has not excluded the possibility of increasing taxation associated with the extraction of natural resources (3). Bolivia seems to have room to increase revenue through direct taxes, and less through sales taxes. If Bolivia could achieve a 25 per cent reduction in the taxation gap (on income and profits) compared to other countries of the Region, nearly one-half point of GDP could be freed up.

As for increasing excise taxes on products that are harmful to health, this looks feasible for tobacco taxes in Bolivia and Peru, but would have a minor impact on revenue. Nevertheless, this is a desirable public health measure and there are possible future savings for society stemming from a reduction in the use of highcost health services and in premature mortality from smoking.

In 2013 Peru raised excise taxes on beer, wine, and spirits and, in 2016, in tandem with the study on fiscal space, it increased excise taxes on tobacco products. The excise taxes increased again in 2018, but were not earmarked specifically for health. As a result, it is currently unlikely that any further increases will occur. And the latest tax reform in Honduras yielded the same result by raising taxes on alcohol $(4,5)$.

Tax expenditures or "foregone tax revenue" (reduced tax collection due to exemptions, reimbursements, deductions, etc.) are one of the most important sources of fiscal space.
In Honduras these are almost equal to sales and import taxes, that is, almost $30 \%$ of total collections (5). A political decision to reduce them could increase revenue by more than one percentage point of GDP in that country. And in Peru it is estimated that reducing foregone tax revenue would generate almost one half point of GDP.

In Suriname, the effect of electricity subsidies is unusually high at several points of GDP (6). The challenge with this source of fiscal space is making the political decision to redirect it, especially away from specific sectors that could be negatively impacted. At any rate, it should be kept in mind that many of these exceptions were created at specific times and for specific reasons, but have not been reevaluated.

Reducing the informal economy is another source of fiscal space that was considered. This is a complex matter involving the informal labor market, with its own dynamics and determinants. The great challenge, in this case, is to institute policies that reduce informal employment and increase tax collection capacity, both through contributions and tax revenue, which would require action by the government as a whole.

In terms of sources, the segmentation caused by labor market conditions makes it necessary to prioritize sources that do not foster segmentation, such as tax revenue that does not only benefit workers in the formal sector.

The studies give estimates of some instances in which very low initial levels of contributions are reported (as in Honduras), which makes them a great potential source. But there is more potential in increasing rates and raising ceilings than in expanding the pool of formal workers (5).

Furthermore, there is a need to increase efficiency in tax collection in order to prevent tax avoidance and evasion, while also promoting the formal job market. Again, these activities would involve the whole of government.

While external sources of financing are somewhat accepted for investment in infrastructure, the studies do not tend to recommend these as a desirable source of fiscal space due to their volatility, lack of sustainability, and the fragmentation caused to the health system when they are implemented.

In fact, in Honduras there is a tradeoff between external assistance and using the country's own resources. Other sectors are prioritized and general tax revenues are not allocated when there is an increase in external aid to the health sector. The new resources have not helped increase the health budget; rather, they free up funding for other sectors (5). Added to this is the segmentation effect, since the generally vertical form of these operations produces self-contained activities for all phases of financing.

Efficiency is a unique source of fiscal space, and the most politically popular one. However in the studies, quantifying the impact of efficiency on health expenditure was complex. Considering the diminishing marginal returns, it is estimated that relatively small gains in efficiency could create significant fiscal space.

There is significant potential in improving mechanisms for the payment and distribution of government expenditure on health, particularly by reducing the inefficiencies and inequities posed by isolated health insurance plans that lack channels for pooling of resources $(3,4)$.

Segmented insurance systems fail to take advantage of economies of scale or the gains to be made from pooling risk. It also increases asymmetrical information and favors adverse selection of the beneficiary population according to the risk of getting sick. 
TABLE 2. Summary of findings of the studies published in this series

\begin{tabular}{|c|c|c|}
\hline Source of fiscal space & Technical feasibility & Political feasibility \\
\hline $\begin{array}{l}\text { Economic growth and favorable } \\
\text { economic conditions }\end{array}$ & $\begin{array}{l}\text { This is business as usual. However, basing fiscal space on } \\
\text { current and future periods of higher growth has not been } \\
\text { enough. }\end{array}$ & $\begin{array}{l}\text { There is almost universal agreement to increase government } \\
\text { expenditure on health by at least the current rate of economic } \\
\text { growth. }\end{array}$ \\
\hline Reprioritization of the budget for health & $\begin{array}{l}\text { Simply increasing the budget is feasible inasmuch as health } \\
\text { accounts for a small part of it. From a technical standpoint, } \\
\text { we must consider the effect of other sectors on health } \\
\text { determinants and be aware that reducing the budget of } \\
\text { sectors associated with health can be counterproductive. }\end{array}$ & The government budget has significant rigidity between sectors. \\
\hline New revenue from general taxes & $\begin{array}{l}\text { The VAT tends to be a quick and easy resource, but } \\
\text { regressive. Income taxes tend to require fiscal reform. }\end{array}$ & $\begin{array}{l}\text { VAT is problematic because it is regressive. Income tax is } \\
\text { difficult because of lobbying by those who would have to pay } \\
\text { more. }\end{array}$ \\
\hline Excise taxes and earmarked taxes & $\begin{array}{l}\text { Taxes on tobacco, alcohol, sugary beverages, and processed } \\
\text { food are easy to calculate and operate }\end{array}$ & $\begin{array}{l}\text { Very feasible and easily understood by the public, but not } \\
\text { possible in light of recent reforms in some countries }\end{array}$ \\
\hline Tax expenditures & Quite easy to identify, according to the context & $\begin{array}{l}\text { Requires political decision and possible dialogue among the } \\
\text { stakeholders, since there will be resistance from those affected }\end{array}$ \\
\hline $\begin{array}{l}\text { Social security contributions earmarked } \\
\text { for health (formal sector) }\end{array}$ & $\begin{array}{l}\text { Of limited efficacy; given how much of the labor market is in } \\
\text { the informal sector, and the segmentation of the systems, } \\
\text { this tends to benefit only formal workers. }\end{array}$ & $\begin{array}{l}\text { Depends on variables associated with the economy and policies } \\
\text { to improve the labor market }\end{array}$ \\
\hline External assistance & $\begin{array}{l}\text { There are few countries left that qualify for the most basic } \\
\text { assistance. Loans are simple, but tend to cause problems } \\
\text { of segmentation and vertical programming. }\end{array}$ & $\begin{array}{l}\text { This is not considered possible, in light of volatility and long- } \\
\text { term sustainability }\end{array}$ \\
\hline Efficiency & $\begin{array}{l}\text { In tandem with transformation processes, it is possible } \\
\text { to identify opportunities for efficiency, such as moving } \\
\text { toward IHSNs with PHC resolution and taking advantage } \\
\text { of efficiencies with pooled funding, which tends to be } \\
\text { singular and thus mitigates segmentation. }\end{array}$ & $\begin{array}{l}\text { This is universally accepted. However, there may be resistance } \\
\text { when measures are applied, unless prior agreements are } \\
\text { reached among actors in the sector. }\end{array}$ \\
\hline
\end{tabular}

VAT, value-added tax; IHSN, integrated health services networks; PHC, primary health care. Source: the author.

On these last two points-the payment system and pooling of risk-the case of Suriname is particularly illustrative. This country has an opportunity to extend its national health fund (known by the Dutch acronym SZF) by applying better payment methods and taking advantage of efficiency gains (6).

Certain common features can be seen the analysis of the political and social viability of the interventions proposed in the papers. For example, the stakeholders consulted prefer to expand the tax base and are generally willing to raise taxes on products that are harmful to health.

There is a predictable consensus around increasing efficiency, while the proposal to increase the tax burden with progressive tax reforms gets a more mixed reception, but is not ruled out. Table 2 summarizes the principal findings.

Finally, the studies emphasize that fiscal space for health focuses on the capacity and viability of additional sources of financing, but that it does not answer all the questions and issues related to health expenditure.

However, the link to health system transformation is crucial, as is the need to determine whether the interventions can be financed sustainably.

The volume of resources needed to make progress toward universal health depends on the costs of care, infrastructure, epidemiological profile, burden of disease, and national prices in each country. As a result, efforts and challenges may vary from country to country.

It is for this reason that decisions on next steps should be tied to a research and action agenda based on studies aimed at linking resources more closely to the goal of universal health, in order to determine the costs of the reforms and transformations needed in each country.

\section{An agenda for research and action}

Numerous studies show the benefits of spending on health as an investment in human capital (16-18): people are rescued from poverty when they do not have to pay for medical care at the point of service; productivity and income levels go up; it spurs economic growth (19-29); and, most importantly, the health and well-being of the population improves (30-32).

Also, along with education, investment in the health sector is regarded as one of the most effective ways to reduce inequities. Therefore, increasing fiscal space for health is also related to reducing inequities $(33,34)$.

A research agenda must be developed for decision-making beyond the analysis of fiscal space, both on technical aspects not yet addressed and on areas of advocacy more explicitly associated with the costs of the transformations needed in the health systems.

As was mentioned, it is necessary to determine the magnitude of the effort to be made in each case. It always is advisable to estimate the cost of the changes and the material and human resource gaps involved, in order to determine the exact amount of additional resources needed to move forward.

Thus, the countries that move forward in health, emerging from the stagnation associated with segmentation and fragmentation and choosing the path to universal health, face two 
FIGURE 2. Agenda for research and action on fiscal space for universal health
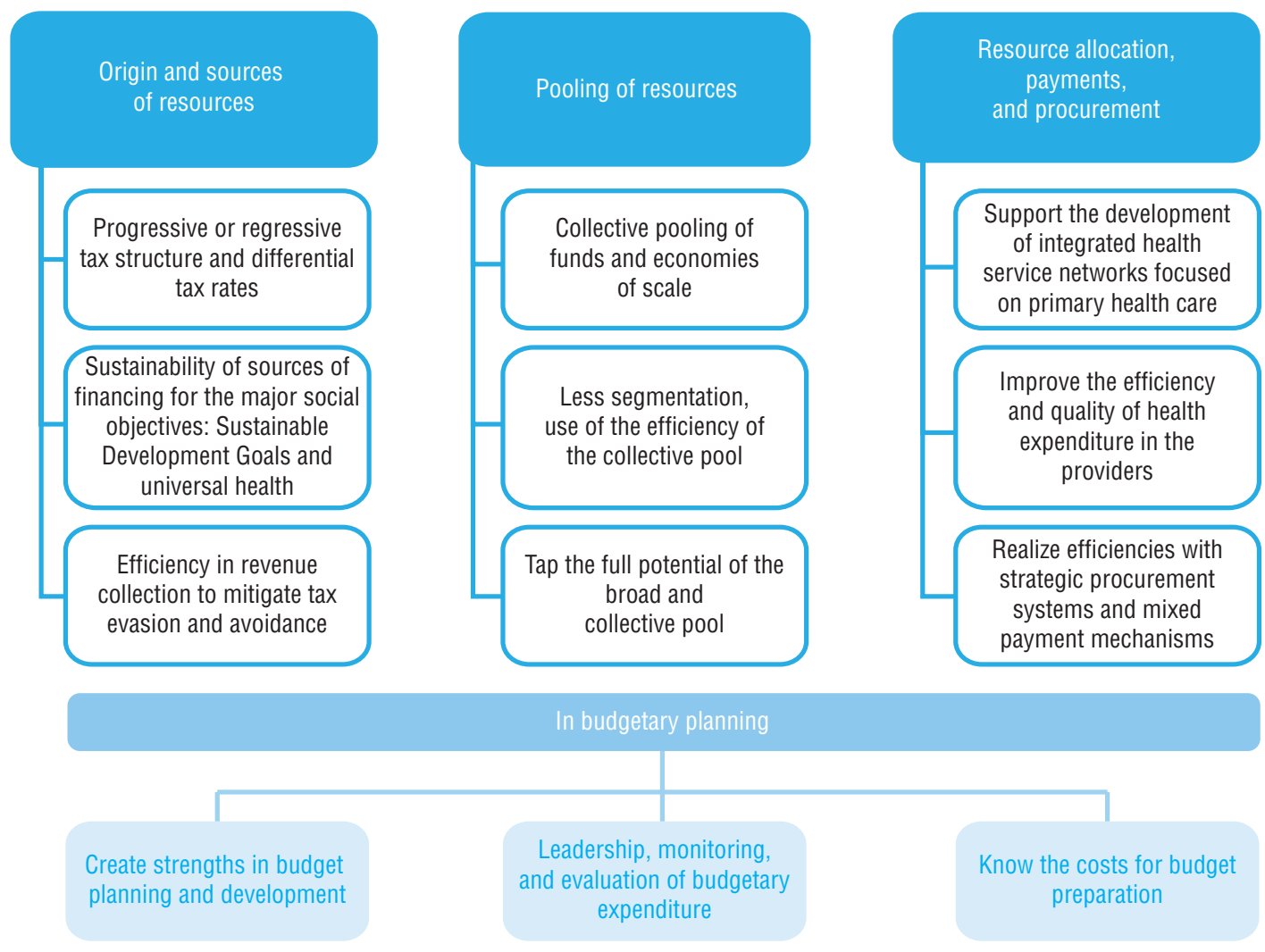

Source: the author.

decisions: which quantification methods to use, and how to analyze political viability $(35,36)$.

The foregoing has implications for each phase of health system financing: sources, pooling of resources, and allocation of resources to providers. Figure 2 summarizes these challenges as described below, with efficiency as a cross-cutting component.

As for sources of financing, there is need for discussion about developing specific tools to increase fiscal space and protect government expenditure on health from economic and political headwinds. For example, a discussion about making health a fiscal priority and the advantages and disadvantages of earmarked taxes would provide important inputs for decision-making in the Region. There are at least two approaches to this: earmarking revenue sources (to ensure that resources from a given public source go to a specific purpose), and earmarking allocations or expenditures (so that a set proportion of general government expenditure is allocated to a specific purpose) (37).

Furthermore, the notion of efficiency in health as a source of fiscal space requires new analytical and conceptual approaches. Although strictly speaking, freeing up resources within a sector does not necessarily generate additional resources for that sector, reallocations due to efficiency gains can help to increase spending in other programs within the health sector.

For example, if government drug procurement is made more efficient by accessing better prices and reducing costs for that specific category, the savings could be used to hire more human resources for health in neglected areas.

In any case, a research agenda on efficiency in health should be based on at least two premises. First, there is no dichotomy between increasing resources for health and using them more efficiently: a combination of both approaches is best. Furthermore, it is not necessary to cut government budgets (doing the same things with fewer resources is not advisable in health). Thus, efficiency is a cross-cutting element of all the basic functions of health financing (38).

A new approach would include an analysis of ways to optimize social efficiency to achieve the major development objectives, such as universal health and the Sustainable Development Goals (SDGs) 2030. This would necessarily a government's social and economic sectors to discuss the taxation system and its ability to facilitate the achievement of these human development objectives by making them part of overall performance evaluations on efficiency and equity in public spending.

Some matters not yet discussed need to be strengthened, such as the potential contribution of subnational taxes, efficient tax collection, the promotion of progressive taxation, and increasing the tax burden.

Furthermore, for technical and political reasons, the effective tax rates in different countries vary by economic sector. However, reducing such inequities-which are often unjustified and simply exist due to inertia-does not always yield additional resources for health. Studies on fiscal space can make these situations visible, which could encourage social dialogue in countries and generate support for spending on health.

In addition, any study on potential resources to expand fiscal space for health should contain a strong political economy component and examine the viability of each potential source. 
As for external sources of funding-especially donations and international aid-there should be a discussion about efficiency in the funding of priority health programs that now benefit from such cooperation. The priority should be sustainability and integrating the health system response into these programs, rather than the sustainability of health activities that are isolated from the rest of the system. In other words, we need more efficient models to deliver those services and to prepare for transitioning to domestic funding. This is because most countries in the region-slowly but surely-are ceasing to be eligible for this aid due to their economic growth and a reduction in the burden of disease (39). Thus the approach should be one of integration and concrete steps to move in that direction. The cost-effectiveness of these actions could be studied in order to estimate the technical efficiency of some interventions. This might guide decision-making on which interventions should continue and which should be reformulated, from the perspective of domestic financing.

As for pooling, countries would benefit from specific analyses that quantify the efficiency gains from better pooling. Beyond possible savings in overhead costs by reducing the number of funds and increasing the size of the pool, it is necessary to analyze how insurance itself improves when the number of protected people goes up due to economies of scale and improved risk distribution.

This is not only relevant for a Region characterized by high segmentation of its health systems, it is particularly important for the countries in the Caribbean subregion, given their relatively smaller populations.

In addition to segmentation (understood as systems that protect specific segments of the population according to occupation or socioeconomic class), pooling can often be fragmented for other reasons such as the regionalization and decentralization of some health systems in the Region. This should also be analyzed through the lens of efficiency.

Similarly, the vertical structure and financing of some public health programs also hinders improved pooling. An analysis of specific cases and concrete options would provide important inputs for decision-making in some countries of the Region. Another necessary but little explored angle in the Region is to find evidence showing that this has implications for health. For example, the literature finds that a broader collective pool or an expanded collective pool is associated with better health outcomes (40).

In the area of resource allocation and payment systems for health services, relevant topics include an analysis of possible causes of inefficiencies stemming from the prevailing allocation mechanisms in the countries, as well as the administration of public finances and the budget in general.

The prevailing system of allocating resources to public providers through historical budgets influenced by lobbyists, with little cost correlation, does little to encourage efficiency or incentivize enhanced productivity in the public sector (38).

Furthermore, potential savings could be made visible by tapping into regional or sub-regional joint drug procurement mechanisms, such as the Strategic Fund of the Pan American Health Organization (PAHO) or the Pharmaceutical Procurement Services of the Organization of Eastern Caribbean States (OECS).

When relating efficiency to how the health care system is organized, there should be a discussion of how some countries in the Region made a lot of progress in expanding fiscal space for health, such as Costa Rica, Cuba and Uruguay. It is important to continue to acknowledge the need for processes that move towards ensuring comprehensive care (through integrated health services networks) for all, and for this to provide the technical tools to facilitate their efficient and feasible implementation.

Countries need to advance toward a defined objective that addresses the structural problems in the systems. It is necessary to aim for efficient, equitable expenditure, a single collective pool, the creation or strengthen comprehensive and integrated health systems, resolutive capacity at the first level of care, coordinated networks, and a primary health care approach that not only offers curative services, but also health promotion and prevention. Evidence shows that increasing health expenditure for this approach can improve the health of the population $(41,42)$.

Resource allocation systems, payment mechanisms, and strategic procurement constitute a field of study in and of themselves. These should be recognized as necessary elements for improving efficiency in a context in which fiscal space is needed and should be used to support efforts to improve the integrated system.

In turn, any available fiscal space should be used to prioritize these approaches that make use of all available resources and avoid payment at the point of service. It is a matter of recognizing that efficiency is a necessary condition for increasing fiscal space for health, within the framework of an effort to transform the health systems.

In that context, with the public sector playing a key role, all phases of budgeting (planning, execution, monitoring) are relevant parts of health planning mechanisms and a pillar of the system's sustainability and efficiency. This pillar should be strengthened and based on actual costs. In some cases, it may be the top priority in addressing financing and payment methods if the financing system is weak; in other cases, it may need to be rebuilt after unsuccessful interventions.

Finally, it is not possible to overlook the macroeconomic context of crisis or sluggish growth in some countries, particularly in South America in recent years. Average growth in Latin America and the Caribbean was projected to be $1.5 \%$ in $2018(43)^{1}$.

In this context, an agenda to promote health expenditure needs to promote countercyclical policy in order to moderate the cycle instead of exacerbating it with measures such as raising interest rates and reducing budgets and social spending, which tend to accelerate the drop in growth (44).

Experience has shown that it is better to support domestic demand, strengthen primary fiscal results prior to payment of foreign debt ( these are clearly improving in the Region), and support measures to reactivate fiscal policy (43), rather than

\footnotetext{
The Economic Commission for Latin America and the Caribbean (ECLAC) estimates that the economies of Latin America and the Caribbean will grow thanks to a turnaround of domestic demand. South America is expected to grow $1.2 \%$ in 2018, while Central America will grow 3.4\%, and the Caribbean $1.7 \%$. The Dominican Republic and Panama will lead the growth of the region, with gross domestic product (GDP) increases of $5.4 \%$ and $5.2 \%$, respectively, followed by Paraguay (4.4\%), Bolivia (4.3\%), and Antigua and Barbuda (4.2\%) This regional growth is occurring in a complex global scenario, characterized by trade conflicts between the United States, China, and other nations, growing geopolitical risks, and a worldwide economic expansion that is slowing down Tax collection in Latin America remains stable, while near-normal inflation is as expected. In the fiscal area, measures aimed at fiscal consolidation in Latin America have given rise to a reduction in the primary deficit, which is predicted to drop from an average of $0.8 \%$ of GDP in 2017 to $0.5 \%$ of GDP in 2018.
} 
promote the austerity of across-the-board budget cuts that endanger the sustainability of health systems, as some of the global experience has shown $(45,46)$.

The structural problems of segmentation and fragmentation in a large majority of health systems in the Region-even in countries with major economic problems- also offer an opportunity to measure the transformation, efficiency, and sustainability of the achievements thus far, within a virtuous framework in which fiscal, social and health policies can be developed.
This is how some countries in some parts of Southeast Asia understood the situation when they instituted major social and health reforms as a significant part of the solution to the 1997-98 crisis in that subregion (47).

Conflicts of interests. None declared by the authors.

Disclaimer. The opinions expressed in this manuscript are the sole responsibility of the author and do not necessarily reflect the opinions or policy of the RPSP/PAJPH and/or PAHO.

\section{REFERENCES}

1. Etienne CF. Investing in universal health in the Americas. Rev Panam Salud Publica. 2018;42:e90. https://doi.org/10.26633 /RPSP.2018.90

2. Cid Pedraza C, Matus-López M, Báscolo E. Espacio fiscal para salud en las Américas: ¿es suficiente el crecimiento económico? Rev Panam Salud Publica. 2018;42:e86. https://doi.org/10.26633 /RPSP.2018.86

3. Matus-López M, Prieto Toledo L, Cid Pedraza C. Evaluación del espacio fiscal para la salud en Perú. Rev Panam Salud Publica. 2016;40(1):64-9.

4. Matus-López M, Cansino Pozo D, Cid Pedraza C, Valdés Romero W. Evaluación del espacio fiscal para salud en Bolivia. Rev Panam Salud Publica. 2018;42:e4. https://doi.org/10.26633/RPSP.2018.4

5. Prieto Toledo L, Montañez Ginocchio V, Cid-Pedraza C. Espacio fiscal para salud en Honduras. Rev Panam Salud Publica. 2018;42:e8. https://doi.org/10.26633/RPSP.2018.8

6. Pan American Health Organizatin/ World Health Organization (PAHO/WHO). Espacio Fiscal para la Salud en Suriname. In press.

7. Rathe M, Hernández P, Van Mosseveld C, Pescetto C, Van de Maele N. Health accounts from past to present for a political arithmetic. Rev Panam Salud Publica. 2018;42:e89. https://doi.org/10.26633 /RPSP.2018.89

8. Petrera Pavone M, Jiménez Sánchez E. Determinantes del gasto de bolsillo en salud de la población pobre atendida en servicios de salud públicos en Perú, 2010-2014. Rev Panam Salud Publica. 2018;42:e20. https://doi.org/10.26633/RPSP.2018.20

9. La Foucade A, Gabriel S, Scott E, Metivier C, Theodore K, Cumberbatch A, et al. Increased taxation on cigarettes in Grenada: potential effects on consumption and revenue. Rev Panam Salud Publica. 2018;42:e195. https://doi.org/10.26633/RPSP.2018.195

10. Pan American Health Organization/ World Health Organization (PAHO/WHO). Espacio Fiscal para la Salud en América Latina. Serie Salud Universal, 2018. Washington D.C.: PAHO, 2018.

11. Pan American Health Organization (PAHO). Resolution CD53.R14. Strategy for Universal Access to Health and Universal Health Coverage. $53^{\text {rd }}$ Directing Council, 66th session of the WHO Regional Committee for the Americas, 2014 Sep29-Oct 3. Washington, D.C.: $\mathrm{PAHO} / \mathrm{WHO} ; 2014$.

12. Heller, P. Understanding fiscal space. Washington, D.C.: International Monetary Fund (IMF); 2005. Policy Discussion Paper, Issue $\mathrm{PDP} / 05 / 4$

13. Economic Commission for Latin America and the Caribbean (ECLAC), Fiscal Panorama of Latin America and the Caribbean, 2018 (LC/ PUB.2018/4-P). Santiago: ECLAC; 2018.

14. Yates, R. Universal Health Coverage Series. Progressive taxes are key. Lancet. 2015;386(9990):227-9.

15. Reeves A, Gourtsoyannis Y, Basu S, McCoy D, McKee M, Stuckler D. Financing universal health coverage-effects of alternative tax structures on public health systems: cross-national modelling in 89 low-income and middle-income countries. Lancet. 2015;386(9990):274-80.

16. Swan T. Economic growth and capital accumulation. Econ Rec. 1956;32(2):334-61.

17. Becker G. Human capital. New York: Columbia University Press; 1964.
18. Schultz T. Investment in human capital. Am Econ Rev. 1961;51(1):1-17.

19. Barro R. Determinants of economic growth. Massachusetts: The MIT Press; 1997.

20. Kalemli-Ozcan S, Ryder H, Weil D. Mortality decline, human capital investment, and economic growth. J Dev Econ. 2000;62(1):1-23.

21. Mayer D. Long-term impact of health on economic growth in Latin America. World Dev. 2001;29(6):1025-33.

22. Bloom D, Canning D, Sevilla J. The effect of health on economic growth: theory and evidence. NBER. 2001; 8587.

23. Howitt P. Health, human capital and economic growth: a schumpeterian perspective. Washington D.C.: Pan American Health Organization; 2005.

24. Jamison D, Lau L, Wang J. Health's contribution to economic growth in an environment of partially endogenous technical progress. In: G. López-Casanovas, B. Rivera \& L. Currais (eds.), Health and economic growth: Findings and policy implications, 67-91. Massachusetts: The MIT Press; 2005.

25. López-Casanovas G, Rivera B, Currais L. Introduction: The role health plays on economic growth. En: G. López-Casanovas, B. Rivera \& L. Currais, (eds.), Health and economic growth: Findings and policy implications, 1-16. Massachusetts: The MIT Press; 2005.

26. Van Zon A, Muysken J. Health as a principal determinant of economic growth. En G. López-Casanovas, B. Rivera \& L. Currais, (eds.), Health and economic growth: Findings and policy implications, 41-65. Massachusetts: The MIT Press; 2005.

27. Weil D. Accounting the effect of health on economic growth. Q J Econ. 2007;122(3): 1265-1306.

28. Osang T, Sarkar J. Endogenous mortality, human capital and economic growth. J Macroecon. 2008;30:1423-45.

29. Gupta M, Barman T. Health, infrastructure, environment and endogenous growth. J Macroecon. 2010;32:657-73.

30. Acemoglu D, Johnson S. Disease and development: the effect of life expectancy on economic growth. J Polit Econ. 2007;115(6): 925-85.

31. Alleyne G, Cohen D. Health, economic growth and poverty reduction. Report Working Group Commission on Macroeconomics and Health, 2002.

32. Sala-i-Martín X. Unhealthy people are poor people... and vice versa. Health and Economic Growth, MIT Press, 2005

33. Wagstaff A. Child health on a dollar a day. Some tentative comparisons. Soc Sci Med. 2003;57:1529-38

34. Basu D, Das D, Basole A, Foley DK. The effect of public expenditure in health on infant mortality: evidence from a panel of Indian States, 1983-84 to 2011-12. Economics Department Working Paper Series 199. Amherst: University of Massachusetts; 2015.

35. Pan American Health Organization/ World Health Organization (PAHO/WHO). Health Financing in the Americas. Health in the Americas 2017. Washington, D.C.: PAHO; 2017.

36. Pan American Health Organization/ World Health Organization (PAHO/WHO). Health System Transformations toward Universal Health. Health in the Americas 2017. Washington, D.C.: PAHO; 2017.

37. Cashin C, Sparkes S, Bloom D. Earmarking for health: from theory to practice (No. WHO/HIS/HGF/HFWorkingPaper/17.5). Geneva: World Health Organization; 2017. 
38. Cid C, Báscolo E, Morales C. La eficiencia en la agenda de la estrategia de acceso y cobertura universales en salud en las Américas. Salud Publica Mex. 2016;58(5): 496-503.

39. Báscolo E, Cid C, Pagano J P, Urrutia MS, Riego AD. The challenge of sustainability of expanded programs on immunization. Rev Panam Salud Publica. 2017;41:e160.

40. Moreno-Serra R, Smith P. Does progress towards universal health coverage improve population health? Lancet. 2012;380: 917-23.

41. Maruthappu M, Watkins J, Mohd Noor A, Williams C, Ali R, Sullivan R. Economic downturns, universal health coverage, and cancer mortality in high-income and middle-income countries, 1990-2010: a longitudinal analysis. Lancet. 2016;388: 684-95.

42. Maruthappu M, Ng KYB, Williams C, Atun R, Zeltner T. Government Health Care Spending and Child Mortality. Pediatrics. $2015 ; 135(4)$

43. Economic Commission for Latin America and the Caribbean (ECLAC). Economic Survey of Latin America and the Caribbean. Evolution of investment in Latin America and the Caribbean: stylized facts, determinants and policy challenges. Santiago: ECLAC; 2018.
44. Krugman P. End this depression now! New York: W.W. Norton \& Company; 2012.

45. Thomson S, Figueras J, Evetovits T, Jowett M, Mladovsky P, Maresso A, et al. Economic crisis, health systems and health in Europe: impact and implications for policy. European Observatory. World Health Organization (Europe). McGraw Hill Open University Press; 2015.

46. Stuckler D, Reeves A, Loopstra R, Karanikolos M, McKee M. Austerity and health: the impact in the UK and Europe. European J Public Health. 2017;27(4):18-21.

47. Kwon H. Advocacy coalitions and health politics in Korea. Soc Policy Admin. 2007;41(2):148-61.

Manuscript received on 15 November 2018. Accepted for publication on 6 December 2018 


\section{Espacio fiscal para el financiamiento sostenible de los sistemas de salud y la salud universal}

RESUMEN Los artículos publicados en esta serie muestran que es posible crear espacio fiscal para la salud en los países. Para esto se requieren decisiones específicas, ya que el crecimiento económico no es suficiente para generar los recursos adicionales necesarios. Los estudios analizan la conveniencia de revisar los gastos tributarios para identificar las exenciones —en general desactualizadas y de escasos beneficios para los países_-; los argumentos para aumentar los impuestos sobre productos dañinos para la salud; y los créditos y donaciones, que no resultan una fuente de ingresos viable para los gobiernos. Los esfuerzos fiscales deben ser acompañados por una mejora de la eficiencia, y la creación progresiva de nuevos ingresos es clave para mejorar la equidad. Es necesario mejorar la recaudación de los recursos fiscales.

Para esto se requiere desarrollar una agenda de investigación y acción que entienda el análisis del espacio fiscal inserto en los procesos de transformación y reforma de los sistemas de salud, que abarque los aspectos técnicos no abordados aún y estudios de la eficiencia social del espacio fiscal para los grandes objetivos de desarrollo como los Objetivos de Desarrollo Sostenible 2030. En los países de la Región de las Américas es imprescindible contar con una gestión eficiente para hacer más y mejor con más recursos, incluso durante los ciclos económicos adversos. Esta debe evidenciarse en todos los niveles, incluidas la solidaridad que logra mejores resultados en salud, los sistemas de asignación de recursos a los proveedores, la compra estratégica de bienes y servicios de salud y el fortalecimiento de los sistemas de planificación presupuestaria.

Palabras clave Financiamiento de la salud; sistema de salud; impuestos; equidad en salud; eficiencia Américas.

\section{Espaço fiscal para o financiamento sustentável dos sistemas de saúde e saúde universal}

RESUMO Os artigos publicados nesta série mostram que é possível criar espaço fiscal para a saúde nos países. Isso requer decisões específicas, já que o crescimento económico não é suficiente para gerar os recursos adicionais necessários. Os estudos analisam o benefício de rever as despesas fiscais para identificar isenções_-geralmente desatualizadas e de baixo benefício para os países_; argumentos para aumentar os impostos sobre os produtos prejudiciais à saúde; e créditos e doações, que não resultam em uma fonte viável de renda para os governos. Os esforços fiscais devem ser acompanhados por uma melhoria na eficiência, e a criação progressiva de novas receitas é fundamental para melhorar a equidade. É necessário melhorar a arrecadação de recursos fiscais.

Para tanto, é necessário desenvolver uma agenda de pesquisa e ação que compreenda a análise do espaço fiscal inserido nos processos de transformação e reforma dos sistemas de saúde, incluindo os aspectos técnicos ainda não abordados e estudos sobre a eficiência social do espaço fiscal para grandes objetivos de desenvolvimento, como os Objetivos de Desenvolvimento Sustentável 2030. Nos países da Região das Américas é essencial ter uma gestão eficiente para fazer mais e melhor com mais recursos, mesmo durante ciclos econômicos adversos. Isso deve ser evidente em todos os níveis, incluindo a solidariedade para alcançar melhores resultados de saúde, a compra estratégica de bens e serviços de saúde e o fortalecimento dos sistemas de planejamento orçamentário.

Palavras-chave Financiamento da assistência à saúde; sistemas de saúde; impostos; equidade em saúde; eficiência; Américas. 